\title{
Short-Term Toxicity Test: Monitoring Klebsiella oxytoca Bacterium Respiration using a Flow Injection Analysis/Conductometric System
}

\author{
José R. Guimarães, *, a Carolina R. T. Farah ${ }^{a}$ and Pedro S. Fadini ${ }^{b}$ \\ ${ }^{a}$ Faculdade de Engenharia Civil, Arquitetura e Urbanismo,Universidade Estadual de Campinas, \\ CP 6021, 13083-852 Campinas-SP, Brazil \\ ${ }^{b}$ Departamento de Química, Universidade Federal de São Carlos, CP 676, \\ 13565-905 São Carlos-SP, Brazil
}

\begin{abstract}
Neste estudo, foi desenvolvido um teste de toxicidade rápido, utilizando-se a bactéria Klebsiella oxytoca como organismo-teste. Ensaios com Escherichia coli foram usados como referência. A inibição do crescimento bacteriano foi avaliada por um sistema de análise por injeção em fluxo (FIA) com detecção condutométrica do $\mathrm{CO}_{2}$ produzido durante o processo respiratório. Os resultados foram expressos em termos de $\mathrm{CE}_{50}$ (concentração efetiva). A bactéria $K$. oxytoca foi mais resistente que a $E$. coli. A ordem de sensibilidade da $K$. oxytoca em relação aos metais foi $\mathrm{Hg}^{2+}>\mathrm{Cd}^{2+}>\mathrm{Cu}^{2+}$ e para E. coli, $\mathrm{Hg}^{2+}>\mathrm{Cu}^{2+}>\mathrm{Cd}^{2+}$. Para o detergente Laborhex 2 (princípio ativo: digluconato de clorexidina), o $\mathrm{CE}_{50}$ foi $1,55 \pm 0,32 \mathrm{mg} \mathrm{L}^{-1}$ e $0,32 \pm 0,10 \mathrm{mg} \mathrm{L}^{-1}$ para $K$. oxytoca e E. coli, respectivamente, enquanto que para o detergente Riodeine Degermant (princípio ativo: iodeto de polivinilpirrolidona-PVP-I), ambas as bactérias apresentaram sensibilidades bem semelhantes, $11,0 \pm 1,7 \mathrm{mg} \mathrm{L}^{-1}$ e $12,0 \pm 2,0 \mathrm{mg} \mathrm{L}^{-1}$, respectivamente.
\end{abstract}

In this study, the Klebsiella oxytoca bacterium was used as a test organism in short-term toxicity evaluations, and Escherichia coli was used as reference. The inhibition of bacterial growth was quantified by flow injection analysis (FIA) via conductometric measurements of the $\mathrm{CO}_{2}$ produced during respiration. The results were expressed as effective concentration $\left(\mathrm{EC}_{50}\right)$ values. $K$. oxytoca was more resistant than $E$. coli in respect to growth inhibition. The metal sensitivity order for $K$. oxytoca was found to be $\mathrm{Hg}^{2+}>\mathrm{Cd}^{2+}>\mathrm{Cu}^{2+}$ and $\mathrm{Hg}^{2+}>\mathrm{Cu}^{2+}>\mathrm{Cd}^{2+}$ for E. coli. The sensitivity to the Laborhex 2 detergent (active ingredient: chlorhexidine digluconate) was $1.55 \pm 0.32 \mathrm{mg} \mathrm{L}^{-1}$ and $0.32 \pm 0.10 \mathrm{mg} \mathrm{L}^{-1}$ for $K$. oxytoca and $E$. coli, respectively. The bacteria showed comparable sensitivities to the Riodeine Degermant detergent (active ingredient: polyvinyl pyrrolidone-iodinePVP-I), of $11.0 \pm 1.7 \mathrm{mg} \mathrm{L}^{-1}$ and $12.0 \pm 2.0 \mathrm{mg} \mathrm{L}^{-1}$, for $K$. oxytoca and E. coli, respectively.

Keywords: short-term toxicity test, Klebsiella oxytoca, Escherichia coli, heavy metals, hospital detergents

\section{Introduction}

The toxicity of a compound is usually defined in terms of the biological response of a particular organism to a toxin, such that toxicity reflects the harmful effects on an organism upon exposure to a given concentration of a chemical agent for a given period of time. In a toxicity test, organisms are used to identify the minimum concentration of a chemical agent that results in disturbance, which determines the level at which exposure becomes harmful.

*e-mail: jorober@fec.unicamp.br
The tests may be used to evaluate the toxicity of chemical products available in the market, to appraise the quality of surface waters, to monitor and verify the efficiency of systems that treat wastewaters and effluents, ${ }^{1,2}$ to evaluate the effects of industrial effluent discharge into surface waters or in wastewater treatment plants, ${ }^{3,4}$ or to evaluate the deleterious actions of industrial products. ${ }^{5}$ The tests can also evaluate the sensitivity of an organism to a substance at various stages of life. ${ }^{6}$

Several methods may be used to evaluate toxicity, and these methods fall into two categories of test: acute and chronic. Acute tests model brief high exposures and measure the harmful effects to the organisms, usually in 
terms of mortality or the onset of symptoms that precede mortality or that occur within the brief period of exposure. Chronic tests evaluate harmful effects on one or more biological functions of the organism, such as reproduction, growth, or behavior, within a period of exposure on the timescale of the full life cycle. ${ }^{7}$

Bioassays that use bacteria as test organisms are classified as short-term toxicity tests. They have certain advantages because the biochemical cycles of bacteria are as complex as the cycles of larger organisms, while the short life cycle displays a swift response to changes in environmental conditions. ${ }^{8}$ Such bioassays are performed in small sample volumes, they are reproducible, they are simple to perform, and they are less expensive than other toxicity tests. ${ }^{9}$

Parvez et al. ${ }^{9}$ classified tests that use bacteria into assay categories that involve monitoring of population growth, substrate consumption, respiration, adenosine tri-phosphate (ATP) luminescence, or bioluminescence inhibition. Bioluminescence inhibition tests employ several bacterial species: Vibrio fischeri, Photobacterium phosphoreum, Vibrio harveyi, or Pseudomonas fluorescens. Among all biochemical processes that take place within cells and bacteria, respiration is the major process that controls the growth of microbial cultures.

In the specialized literature there are studies showing the use of the bacterium Escherichia coli as a test organism to evaluate the toxicity of metals, antibiotics, organic compounds, textile effluent, sediment and fuel. ${ }^{10-14}$

Like Escherichia coli, Klebsiella oxytoca bacterium belongs to the enterobacter family. It may cause infections of the urinary, respiratory and gastrointestinal tracts. The $K$. oxytoca bacterium is one of the sources of hospital infection and can be detected in distilled water containers, resuscitation apparatus and hand-washing scrubbers. According to Reiss et al., ${ }^{15}$ this bacterium is resistant to disinfectants, probably mediated by capsule formation. Due to its resistance, this bacterium can be used as an alternative organism in short-term toxicity tests.

The aim of this study was to evaluate a short-term toxicity test using the Klebsiella oxytoca bacterium as test organism. Bacteria respiration was monitored using a flow injection analysis (FIA) system with conductometric detection.

\section{Experimental}

\section{Chemical species evaluated}

This work evaluated the following potentially toxic substances: antibiotic tetracycline, the toxic metals $\mathrm{Hg}^{2+}$,
$\mathrm{Cd}^{2+}$, and $\mathrm{Cu}^{2+}$, plus two hospital detergents (Laborhex 2 and Riodeine Degermant).

A $250 \mathrm{mg} \mathrm{L}^{-1}$ tetracycline solution was prepared by dissolving the contents of one EMS brand capsule of the antibiotic in deionized water. This solution was stored as aliquots in Eppendorf tubes, protected from light, and frozen until use in an assay. The concentrations ranged from 0.008 to $1 \mathrm{mg} \mathrm{L}^{-1}$ tetracycline. This reference antibiotic was used in the sensitivity testing successive bacteria generations.

Metal chloride Merck reference solutions were diluted in calibrated volumetric flasks to concentrations of $1 \mathrm{~g} \mathrm{~L}^{-1}$. The concentration ranged from 1 to $100 \mu \mathrm{g} \mathrm{L}^{-1}$ for $\mathrm{Hg}^{2+}$, from 0.25 to $100 \mathrm{mg} \mathrm{L}^{-1}$ for $\mathrm{Cd}^{2+}$, and from 1 to $200 \mathrm{mg} \mathrm{L}^{-1}$ for $\mathrm{Cu}^{2+}$.

The detergents were diluted with consideration for the active ingredient. Laborhex 2 contained $20.0 \mathrm{~g} \mathrm{~L}^{-1}$ chlorhexidine digluconate, so the assay concentrations ranged from 0.1 to $5 \mathrm{mg} \mathrm{L}^{-1}$. The Riodeine Degermant contained $100.0 \mathrm{~g} \mathrm{~L}^{-1}$ polyvinyl pyrrolidone-iodine (PVP-I), and the assay concentrations ranged from 5 to $15 \mathrm{mg} \mathrm{L}^{-1}$.

\section{Test organisms}

Bacteria K. oxytoca (CIP 79.32) and E. coli (ATCC 25922) were acquired from the André Tosello Tropical Foundation for Research and Technology in Brazil.

\section{Culture medium for bacteria growth}

The culture medium was prepared by adding $1.6 \mathrm{~g}$ $\mathrm{KH}_{2} \mathrm{PO}_{4}$ (Synth), $1.6 \mathrm{~g} \mathrm{~K}_{2} \mathrm{HPO}_{4}$ (Merck), $1.0 \mathrm{~g} \mathrm{NaCl}$ (Synth), $4.0 \mathrm{~g}\left(\mathrm{NH}_{4}\right)_{2} \mathrm{SO}_{4}$ (Merck), $0.1 \mathrm{~g} \mathrm{MgSO}_{4}$ (Merck), and $0.5 \mathrm{~g}$ citric acid (Merck) per liter of water, and the $\mathrm{pH}$ was adjusted to 7.2 using a $4 \mathrm{~mol} \mathrm{~L}^{-1} \mathrm{NaOH}$ solution (Merck). The solution was boiled and cooled to $90{ }^{\circ} \mathrm{C}$, and $2.5 \mathrm{~g}$ glucose (Ecibra) was added. This procedure was described by Dowards and Barisas, ${ }^{16}$ and adapted by Jardim et al., ${ }^{12}$ although the quantity of magnesium sulfate used was adjusted from 0.7 to $0.1 \mathrm{mg} \mathrm{L}^{-1}$.

\section{Toxicity test procedure}

The culture medium was inoculated with the bacteria and left in an oven at $37^{\circ} \mathrm{C}$ until the bacterial suspension became cloudy. It was then placed in a water bath at $37^{\circ} \mathrm{C}$, and the $\mathrm{CO}_{2}$ was monitored until its concentration reached $0.50 \mathrm{mmol} \mathrm{L}^{-1}$. One-hundred milliliter aliquots were transferred from this bacteria stock suspension to $125 \mathrm{~mL}$ Erlenmeyer flasks maintained at $37^{\circ} \mathrm{C}$ and containing the test chemicals. 
No test chemicals were added to the control flask. An analytical curve was constructed from the reference solutions with concentrations of $0.25,0.50,1.00,2.00$, and $4.00 \mathrm{mmol} \mathrm{L}^{-1}$ for each assay. Culture medium without bacteria was used as the blank. The cultures were monitored every $20 \mathrm{~min}$ with the following order of analysis: control, blank, contaminated cultures, and finally the control once again, until the analytical signal of the control reached the same intensity as the signal of the reference solution with the highest concentration, which was $4 \mathrm{mmol} \mathrm{L}^{-1}$.

\section{$\mathrm{CO}_{2}$ determination using the FIA system}

The FIA system used here has been described previously in Jardim et al., ${ }^{12}$ and is used for short-term toxicity tests, which monitored bacterial growth (E. coli) by measuring the $\mathrm{CO}_{2}$ production from the microorganism's respiration process.

The FIA system used in the toxicity assay was composed of a peristaltic pump, a samples and standards injector, a diffusion cell, a conductivity cell, reagent delivery tubes, ionic exchange resins, a conductivity meter, a recorder, and a water bath. A schematic diagram is shown in Figure 1.

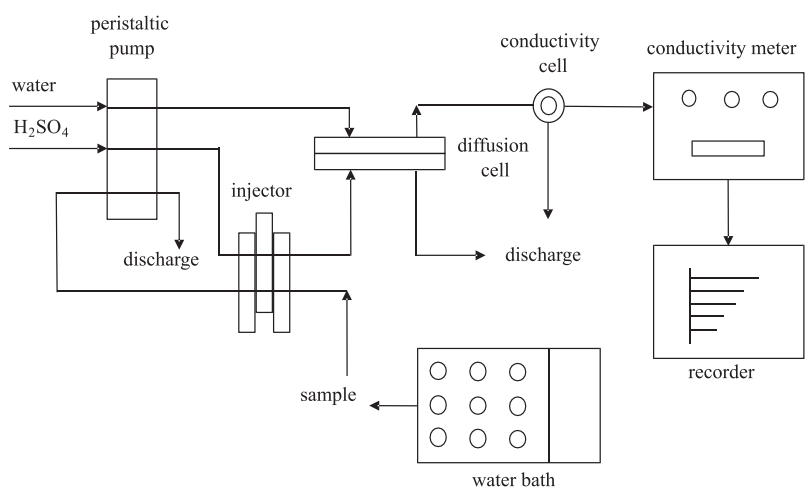

Figure 1. Diagram of the FIA/conductometric system used to determine the $\mathrm{CO}_{2}$ concentration in toxicity assays.

The analytical procedure consisted of the following steps: a $100 \mu \mathrm{L}$ aliquot was delivered to a sampling ring and was manually injected into a $0.2 \mathrm{~mol} \mathrm{~L}^{-1}$ sulfuric acid carrier flow. According to equation 1, the displaced equilibrium favored formation of $\mathrm{CO}_{2}$ and $\mathrm{H}_{2} \mathrm{O}$.

$$
2 \mathrm{H}_{\text {(aq) }}^{+}+\mathrm{CO}_{3 \text { (aq) }}^{2-}=\mathrm{H}_{\text {(aq) }}^{+}+\mathrm{HCO}_{3 \text { (aq) }}^{-}=\mathrm{H}_{2} \mathrm{CO}_{3 \text { (aq) }}=\mathrm{CO}_{2 \text { (aqu) }}+\mathrm{H}_{2} \mathrm{O}
$$

A fraction of the carbon dioxide gas formed permeated into the diffusion cell through a Teflon ${ }^{\circledR}$ membrane and into the flow of deionized water, which was continually monitored for conductivity. In this water flow, acid hydrolysis of $\mathrm{CO}_{2}$ occurred, which increased the conductivity in proportion to the concentration of the carbonic species present in the original sample.

\section{Calculation of the $\mathrm{CO}_{2}$ concentration and effective concentration (EC)}

Short-term toxicity tests using $K$. oxytoca and $E$. coli bacteria measured the inhibition of microbial respiration $\left(\mathrm{CO}_{2}\right)$ by the test compounds. The $\mathrm{CO}_{2}$ concentration in all flasks was obtained by interpolation of the analytical curve. $^{13}$

Bacterial growth was verified by the increase in $\mathrm{CO}_{2}$ concentration in the control (bacterial suspension without the toxic agent). Figure 3 shows the bacterial growth of the control and the suspensions with increasing concentration of the metal $\mathrm{Cd}^{2+}$.

The effective concentration $\left(\mathrm{EC}_{50}\right)$ was obtained from the chart of percent inhibition versus concentration of the test compound over an exposure time, which was determined by the bacterial growth of the control in the $\mathrm{CO}_{2}$ concentration range $0.5-4 \mathrm{mmol} \mathrm{L}^{-1}$ (Figure 3). Equation 2 provides an expression for the effective concentration,

$\mathrm{EC}=\left[\frac{(\mathrm{C}-\mathrm{A})}{\mathrm{C}}\right] \times 100$

where $\mathrm{C}$ is the difference between the final and initial $\mathrm{CO}_{2}$ concentrations in the control, and $\mathrm{A}$ is the difference between the final and initial $\mathrm{CO}_{2}$ concentrations in the sample.

\section{Results and Discussion}

The bacterial growth times in the controls, within the 0.5-4 mmol L $\mathrm{L}^{-1}$ concentration range, differed for each species. Table 1 lists the number of assays performed and the average time it took the bacteria to double.

Table 1. Number of assays performed and the bacteria doubling time

\begin{tabular}{lcc}
\hline Bacteria & $\begin{array}{c}\text { Number of assays } \\
\text { performed }\end{array}$ & $\begin{array}{c}\text { Doubling } \\
\text { time / min }\end{array}$ \\
\hline K. oxytoca & 37 & $29.5 \pm 3.4$ \\
E. coli & 30 & $33.9 \pm 3.2$ \\
\hline
\end{tabular}

According to the $\mathrm{CO}_{2}$ concentration, $K$. oxytoca grew faster than $E$. coli with duplication times of $29.5 \pm 3.4 \mathrm{~min}$ and $33.9 \pm 3.2 \mathrm{~min}$, respectively. The F-test for the comparison of standard deviations showed that the variances of the two cases did not differ significantly; however, the significance test (t-test) for the comparison of 
two experimental means pointed a significant difference at $\mathrm{p}=0.05$ (Miller and Miller $^{17}$ ).

The assay toxicity method described here was optimized by varying the concentrations of the test compounds to identify concentrations that would be representative of an inhibition interval between 0 and $100 \%$. The assays were performed at least in duplicate.

The tetracycline assays provided a reference assay for comparison. The bacterium may undergo genetic mutations due to several factors. One such common mutation is caused by transfer of the original strain to prolong its use. Each transfer represents a new generation and, after several transfers, the bacteria may display different effective concentrations $\left(\mathrm{EC}_{50}\right)$. Prior to conducting the assay with a test compound, an assay must be performed using a solution in which the inhibition concentration or the $\mathrm{EC}_{50}$ is known, and which acts as a control for the bacterial activity. All toxicity tests were accompanied by such an activity control assay, performed by growing the strain in media containing $0.1 \mathrm{mg} \mathrm{L}^{-1}$ tetracycline to verify the bacterial activity. This concentration provided inhibition of around $61 \%$ relative to the control. The $\mathrm{EC}_{50}$ values remained constant throughout the period of experiments showing that no significant variations in the characteristics of both bacteria occurred.

The results demonstrated that both bacterial species had similar responses to the reference antibiotic $\left(\mathrm{EC}_{50}=0.08 \pm 0.01 \mathrm{mg} \mathrm{L}^{-1}\right)$. No effects were noted up to concentrations of $0.02 \mathrm{mg} \mathrm{L}^{-1}$. Inhibition began beyond a concentration of $0.05 \mathrm{mg} \mathrm{L}^{-1}$ and was complete after $0.5 \mathrm{mg} \mathrm{L}^{-1}$.

The sensitivity of the assay to a commercial antibiotic indicates the assays' potential for applications in healthcare. For example, antibiograms may be used to determine the susceptibility of a contaminated material of biological origin to a range of antibiotics.

\section{Comparison among metals}

Figure 2 shows the behavior of the bacteria in the presence of $\mathrm{Hg}^{2+}$. No effects on growth were observed relative to the control in either species in the presence of up to $25 \mu \mathrm{g} \mathrm{L} \mathrm{L}^{-1} \mathrm{Hg}^{2+}$. An inhibition response was observed starting at $50 \mu \mathrm{g} \mathrm{L}^{-1}$ and became significant for E. coli, with $70-80 \%$ inhibition. $K$. oxytoca inhibition levels were in the range $40-50 \%$. E. coli proved to be more sensitive than $K$. oxytoca to this compound.

In the presence of $\mathrm{Cd}^{2+}$, the inhibition effects on the bacteria differed at a concentration of $2.5 \mathrm{mg} \mathrm{L}^{-1}$, which was the lowest tested. The $K$. oxytoca (Figure 3 ) response was comparable to the response of the control, whereas E. coli showed slight inhibition (Figure not shown). The $\mathrm{EC}_{50}$ of $\mathrm{Cd}^{2+}$ for $\mathrm{K}$. oxytoca (Figure 4) was 3 times greater than that for $E$. coli (Table 2). Thus, it was possible to conclude that cadmium showed higher toxicity to $E$. coli, when compared to $K$. oxytoca bacteria.
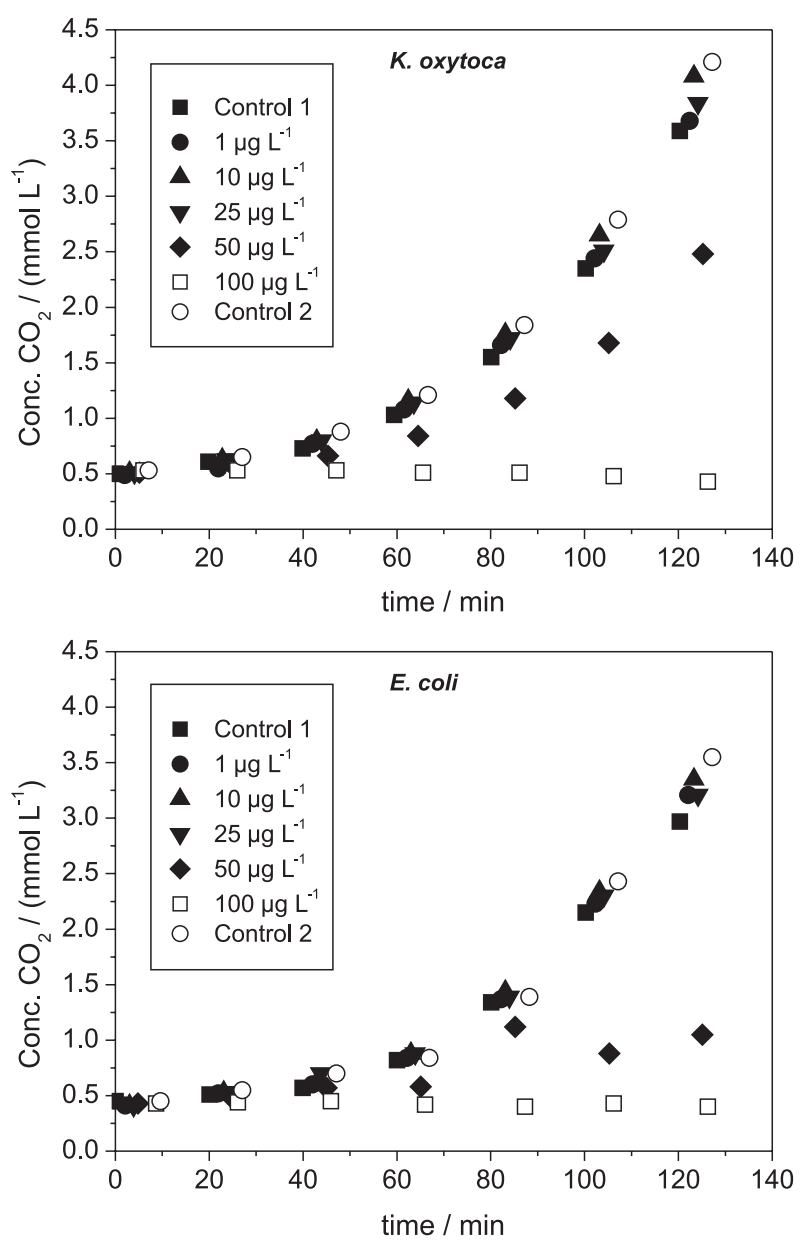

Figure 2. Bacterial growth of $K$. oxytoca and E. coli in the presence of $\mathrm{Hg}^{2+}$.

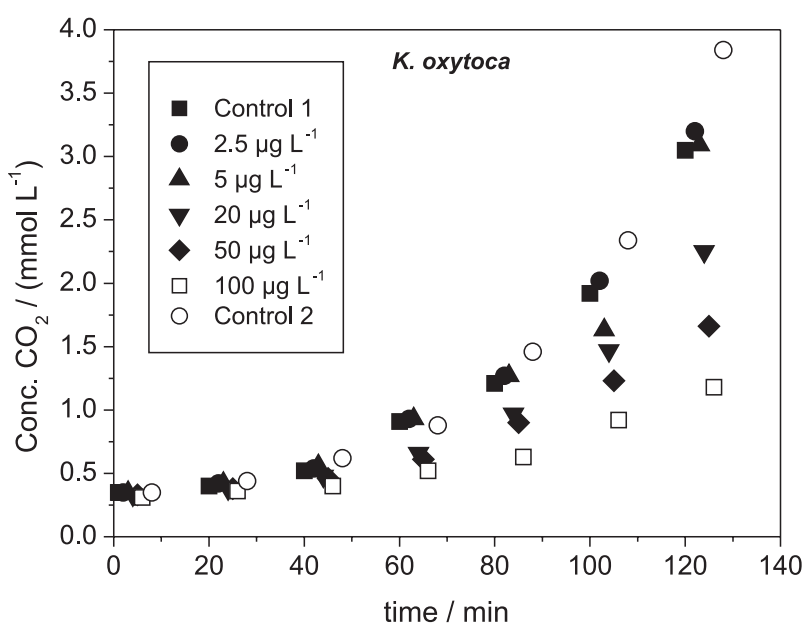

Figure 3. Bacterial growth of $K$. oxytoca in the presence of $\mathrm{Cd}^{2+}$. 


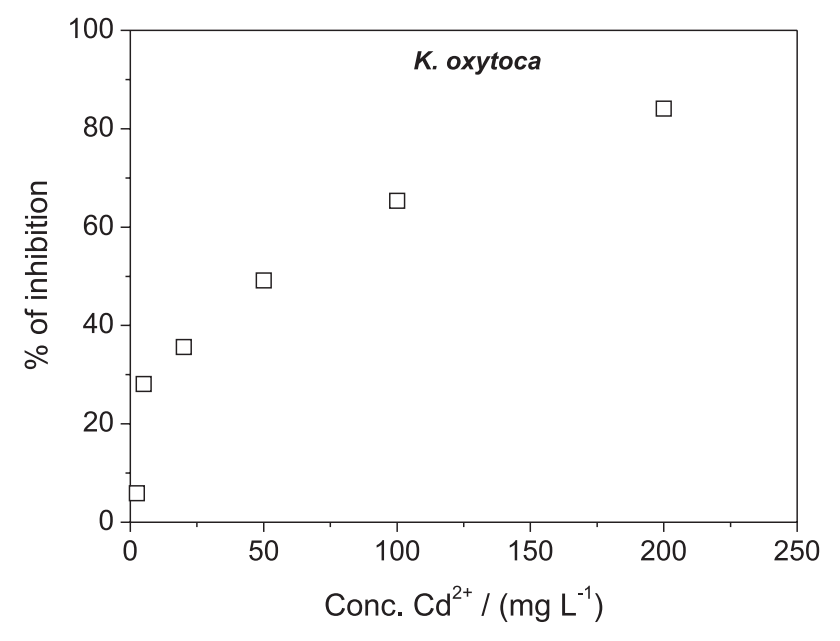

Figure 4. Effective concentration (EC) of $\mathrm{Cd}^{2+}$ for $K$. oxytoca.

E. coli proved to be far more sensitive than $K$. oxytoca to $\mathrm{Cu}^{2+}$. The compound displayed growth inhibition starting at $0.25 \mathrm{mg} \mathrm{L}^{-1}$ for $E$. coli, and exposure to $10 \mathrm{mg} \mathrm{L}^{-1} \mathrm{Cu}^{2+}$ resulted in $K$. oxytoca inhibition comparable to that of the control. The $\mathrm{EC}_{50}$ for $\mathrm{Cu}^{2+}$ for $K$. oxytoca was 70 times greater than that for E. coli (Table 2).

A thorough evaluation of the toxic effects of a test compound requires that toxicity be tested for an array of organisms that are representative of the different trophic levels. The sensitivities of $E$. coli and $K$. oxytoca were compared with previous reports of the sensitivities of other organisms to the same toxic agents, as shown in Table 2. The organisms assayed in the literature were E. coli, Vibrio fischeri or Microtox ${ }^{\circledR}$, and the microcrustacean Daphnia magna.

Toxic agents act differently on microorganisms. To estimate safe environmental concentration limits, several tests must be performed simultaneously. The assays must also be performed under different conditions. Among the organisms listed in Table 2, D. magna was more sensitive than the bacteria towards metals.

Several conclusions could be drawn with respect to the bacteria used in this study and submitted to the same environmental conditions. $K$. oxytoca was more resistant than $E$. coli to all test compounds. The order of sensitivity was $\mathrm{Hg}^{2+}>\mathrm{Cd}^{2+}>\mathrm{Cu}^{2+}$ for $K$. oxytoca and $\mathrm{Hg}^{2+}>\mathrm{Cu}^{2+}>$ $\mathrm{Cd}^{2+}$ for E. coli.

Organisms at the same trophic level may display different sensitivities toward a specific compound, as suggested by the inverted sensitivities to $\mathrm{Cd}^{2+}$ and $\mathrm{Hg}^{2+}$. The original microorganisms may have had contact with different metals and may have adapted prior to being used in this assay. Different laboratories may obtain variable results, as pointed by Cotman et al..${ }^{21}$ who described an interlaboratory trial using D. magna tests for wastewater matrices. The coefficient of variation was as high as $62.9 \%$.

$\mathrm{Hg}^{2+}$ was the most toxic agent among the metals tested for the majority of organisms shown in Table 2. $\mathrm{Cu}^{2+}$ was the second most toxic (with the exception of toxicity toward $K$. oxytoca and one Microtox test), followed by $\mathrm{Cd}^{2+}$.

It is important to point out that in the present study the results were obtained from total concentration of metals and the activity or bioavailability of the test compounds in the culture medium was not tested. However, Jardim et al., ${ }^{12}$ and Gimenez and co-workers, ${ }^{14}$ have previously verified the activity of $\mathrm{Cu}^{2+}, \mathrm{Cd}^{2+}$, and $\mathrm{Hg}^{2+}$ in the culture medium in a toxicity test similar to this study. They concluded that the toxicity is reduced in the presence of the culture medium.

Toxicity data for tests with pure substances performed in the laboratory are important for the evaluation of environmental risks and also for setting water quality criteria. Aquatic organisms are not normally exposed to isolated substances. Rather, they are exposed to mixtures.

The interactions between organic compounds and toxic metals can change the bioavailability of a metal and reduce its toxicity. The toxicity of metals is more closely correlated with the free ion concentration than with the total metal concentration or the concentration of the complexed forms..$^{22}$

Comparison among active ingredients in hospital detergents

Klebsiella spp. bacteria are an important nosocomial pathogen. The incidence of Klebsiella infection detected in immunocompromised hospitalized patients in hospitals

Table 2. Comparison of the $\mathrm{EC}_{50}$ and $\mathrm{IC}_{50}$ of 6 toxicity tests for $\mathrm{Hg}^{2+}\left(\mu \mathrm{g} \mathrm{L}^{-1}\right), \mathrm{Cd}^{2+}\left(\mathrm{mg} \mathrm{L}^{-1}\right)$, and $\mathrm{Cu}^{2+}\left(\mathrm{mg} \mathrm{L}^{-1}\right)$ reported in the literature

\begin{tabular}{|c|c|c|c|c|c|c|}
\hline \multirow[b]{2}{*}{ Test compounds } & \multicolumn{6}{|c|}{ Toxicity tests } \\
\hline & $\begin{array}{c}\text { K. oxytoca } \\
\mathrm{EC}_{50}{ }^{\mathrm{a}}{ }^{\mathrm{a}}\end{array}$ & $\begin{array}{l}\text { E. coli } \\
\mathrm{EC}_{50}{ }^{a}{ }^{2}\end{array}$ & $\begin{array}{l}\text { E. coli } \\
\mathrm{EC}_{50}^{60, \mathrm{~b}, 14} \\
\end{array}$ & $\begin{array}{l}\text { Microtox }{ }^{\circledR} \\
(15 \mathrm{~min})^{18}\end{array}$ & Microtox ${ }^{19}$ & $\begin{array}{c}\text { D. magna } \\
(24 \mathrm{~h})^{20}\end{array}$ \\
\hline $\mathrm{Hg}^{2+}$ & $56.5 \pm 12.14$ & $49.30 \pm 0.49$ & - & $30 \pm 10$ & $380(15 \min )^{c}$ & 1.6 \\
\hline $\mathrm{Cd}^{2+}$ & $57.45 \pm 3.43$ & $17.57 \pm 4.33$ & 47.4 & $56.83 \pm 56.51$ & $0.30(15 \mathrm{~min})$ & 0.98 \\
\hline $\mathrm{Cu}^{2+}$ & $69.41 \pm 6.14$ & $1.78 \pm 0.01$ & 35.7 & $1.29 \pm 1.69$ & $1.02(5 \mathrm{~min})$ & 0.022 \\
\hline
\end{tabular}

${ }^{\mathrm{a}}$ Results from this study. ${ }^{\mathrm{b}}$ The bioavailability of the metal was considered. ${ }^{\mathrm{c}}$ Result were extrapolated. 
Table 3. Comparison of the $\mathrm{EC}_{50}$ for hospital detergents

\begin{tabular}{lcccc}
\hline & \multicolumn{4}{c}{$\mathrm{EC}_{50} /\left(\mathrm{mg} \mathrm{L}^{-1}\right)$} \\
Hospital detergents & \multicolumn{2}{c}{ K. oxytoca } & \multicolumn{2}{c}{ E. coli } \\
& $\mathrm{N}$ & & $\mathrm{N}$ & \\
\hline Laborhex 2 & 4 & $1.55 \pm 0.32$ & 3 & $0.32 \pm 0.10$ \\
Riodeine Degermant & 7 & $11.00 \pm 1.70$ & 7 & $12.00 \pm 2.00$ \\
\hline
\end{tabular}

is around $5-7 \% .^{23}$ The main cause of hospital infections is the incorrect asepsis of equipment and the hands of hospital staff. To prevent Klebsiella oxytoca outbreaks in hospitals, the efficiency of detergents and disinfectants need to be evaluated. This can be performed using quick tests, as described in this study.

Laborhex and Riodeine detergents are indicated as disinfectant for the hands and arms of the surgical and laboratorial team and for pre-surgical preparing of patients skin.

Concerning to laborhex detergent, it was verified that $0.50 \mathrm{mg} \mathrm{L}^{-1}$ of the compound was the highest concentration used in the test for $E$. coli, causing a high inhibition; this same concentration was the lowest used in the test with $K$. oxytoca. Table 3 shows the $\mathrm{EC}_{50}$ values obtained for both bacteria. The $\mathrm{EC}_{50}$ was five times higher for $K$. oxytoca than $E$. coli. So, the $E$. coli was more sensitive to laborhex detergent and, therefore, $K$. oxytoca was more suitable than $E$. coli for evaluating the efficiency of detergents based on chlorhexidine. As shown in Table 3, both species presented similar sensitivities to Riodeine, once the $\mathrm{EC}_{50}$ values were statistically equal.

Laborhex 2 showed bactericidal action toward $E$. coli that was superior to the action of Riodeine, whereas $K$. oxytoca was more resistant than E. coli to Laborhex 2 . $K$. oxytoca resistance against the disinfectant was probably aided by the formation of capsules visible as mucold colonies, as reported by Reiss et al..$^{15}$

The detergent test compound results showed the potential for application of the toxicity assay developed here. The efficiency of the detergents was evaluated from the standpoint of their quality as sanitary products. ${ }^{24}$

\section{Conclusions}

The $K$. oxytoca appeared to be a good test organism because the $\mathrm{EC}_{50}$ values obtained in the toxicity assays showed low standard deviations, which denotes reproducibility.

The bacteria proved to be highly sensitive to tetracycline. This drug may be used as a reference to confirm that a strain has retained its characteristics during storage and handling.
For all the metals $\left(\mathrm{Hg}^{2+}, \mathrm{Cd}^{2+}\right.$, and $\left.\mathrm{Cu}^{2+}\right)$ analyzed and both detergents (Laborhex 2 and Riodeine Degermant), $K$. oxytoca proved to be more resistant than E. coli., indicating that Klebsiella as a more reliable organism for efficiency assays of detergents used in hospitals than E. coli.

Finally, the toxicity test proposed in this study may be used as a complementary test when a battery of toxicity tests are required to characterize both pure substances and mixed compounds.

\section{Acknowledgments}

The authors would like to thank the São Paulo Research Foundation (FAPESP) and the Coordenação de Aperfeiçoamento de Pessoal de Nível Superior (CAPES).

\section{References}

1. Arslan-Alaton, I.; Eremektar, G.; Germirli-Babuna, F.; Insel, G.; Selcuk, H.; Ozerkan, B.; Teksoy, S.; Water Sci. Technol. 2005, 52, 309.

2. Jamroz, T.; Ledakowicz, S.; Miller, J. S.; Sencio, B.; Environ. Toxicol. 2003, 18, 187.

3. Tisler, T.; Zagorc-Koncan, J.; Water Sci. Technol. 1994, $30,107$.

4. Mamais, D.; Noutsopoulos, C.; Stasinakis, A. S.; Kouris, N.; Andreadakis, A. D.; Water Environ. Res. 2008, 80, 484.

5. Ezemonye, L. I. N.; Ogeleka, D. F.; Okieimen, F. E; Chem. Ecol. 2007, 23, 131.

6. Ferrer, L.; Andrade, S.; Austeasuain, R.; Marcovecchio, J.; Ecotoxicol. Environ. Saf. 2006, 65, 209.

7. Conselho Nacional do Meio Ambiente (CONAMA); Resolução n. 357 de 15 de março de 2005, Brasília, DF, Brasil, 2005.

8. Bitton, G.; Crit. Rev. Environ. Control. 1983, 13, 51.

9. Parvez, S.; Venkataraman, C.; Mukherji, S.; Environ. Int. 2006, 32, 265.

10. Moraes, S. G.; Freire, R. S.; Durán, N.; Chemosphere 2000, 40, 369.

11. Jardim, W. F., Moraes, S. G., Takiyama, M. M. K.; Water Res. 1997, 31, 1728.

12. Jardim, W. F.; Pasquini, C.; Guimarães, J. R.; Faria, L. C.; Water Res. 1990, 24, 351.

13. Guimarães, J. R.; Jardim, W. F.; Quim. Nova 1993, 16, 28.

14. Jardim, W. F.; Canela, M. C.; Gimenez, S. M. N.; Moraes, S. G.; Chem. Speciation Bioavailability 1993, 5, 97.

15. Reiss, I.; Borkhardt, A.; Füssle, R.; Sziegoleit, A.; Gortner, L.; The Lancet 2000, 356, 310.

16. Dowards, E. J.; Barisas, B. G.; Aquat. Toxicol. 1984, 4, 129.

17. Miller, J. N.; Miller, J. C.; Statistics and Chemometrics for Analytical Chemistry, $4^{\text {th }}$ ed.; Prentice Hall, New Jersey, USA, 2000. 
18. Greene, J. C.; Miller, W. E.; Debacon, M. K.; Long, M.; Bartels, C. L; Arch. Environ. Contam. Toxicol. 1985, 14, 659.

19. Sillanpãã, M.; Oikari, A.; Chemosphere 1996, 32, 1485.

20. Sorvari, J.; Sillanpãã, M.; Chemosphere 1996, 33, 1119.

21. Cotman, M.; Drolc, A.; Milenko, R.; Tisler, T.; Int. J. Environ. Pollut. 2007, 31, 13.

22. Kim, K. T.; Lee, Y. G.; Kim, S. D.; Environ. Int. 2006, 32, 487.

23. Brisse, S.; Milatovic, D.; Fluit, A. C.; Verhoef, J.; Schmitz, F.-J.; Eur. J. Clin. Microbiol. Infect. Dis. 2000, 19, 64.
24. Santos, A. A.; Nascimento, A. R.; Kondo, M. M.; Grassi, M. T.; Annals of the Brazilian Chemical Society, $23^{\text {th }}$ Meeting, Poços de Caldas, MG, Brasil, 2000.

Submitted: March 23, 2011

Published online: January 17, 2012

FAPESP has sponsored the publication of this article. 